\title{
RELATIONSHIP BETWEEN RETENTION FACTORS AND AFFECTIVE ORGANISATIONAL COMMITMENT AMONG KNOWLEDGE WORKERS IN MALAYSIA
}

\author{
Nilufar Ahsan', David Yong Gun Fie ${ }^{2}$, \\ Yeap Peik Foong ${ }^{3}$, Syed Shah Alam ${ }^{4}$ \\ 1,2,3 Faculty of Management, Multimedia University, 63100 Cyberjaya, Selangor, Malaysia \\ ${ }^{4}$ Faculty of Economics and Management, Universiti Kebangsaan Malaysia, \\ UKM Bangi, Selangor, Malaysia \\ E-mails: ${ }^{1}$ nilu_far70@yahoo.com (corresponding author); ${ }^{2}$ gfyong@mmu.edu.my; \\ 3pfyeap@mmu.edu.my; ${ }^{4}$ shahalam@ukm.my
}

Received 25 September 2011; accepted 06 June 2012

\begin{abstract}
This research explores the issues that influence affective commitment among knowledge workers in Malaysia. The determinants of affective commitment among knowledge workers that have been examined from the Malaysian knowledge workers' perspective under this study including compensation, career opportunity, training and development, supervisor support, job autonomy, work life policies and skill varieties. A conceptual framework is constructed based on the retention factors and research hypothesis are then developed in order to focus attention on sets of factors that influences affective commitment among knowledge workers in Malaysia. Results of regression analyses revealed that all but supervisor support and skill variety were significant predictors of affective commitment among knowledge workers in Malaysia. Recommendations for future research are presented for industry bodies involved in supporting retention of knowledge workers in Malaysia.
\end{abstract}

Keywords: knowledge workers, affective commitment, retention factors, Malaysia.

Reference to this paper should be made as follows: Ahsan, N.; Fie, D. Y. G.; Foong, Y. P.; Alam, S. S. 2013. Relationship between retention factors and affective organisational commitment among knowledge workers in Malaysia, Journal of Business Economics and Management 14(5): 903-922.

JEL Classification: M12.

\section{Introduction}

Recently researchers, managers and supervisors in organisations are very much concerned about employee retention and the employees' turnover which are two most important topics in organisational research. Low retention rate of employees ultimately give the result that extra time and money are spent on recruiting, selecting, and training new employees that could have been spent on other activities like performance improvement or career development of employees (Abbasi, Hollman 2000; Arkin 1997; Muchn- 
insky 1997; Sighter, Adams 1999). Moreover, Sightler and Adams (1999) reported that organisations may experience a decrease in performance, efficiency, and morale, and an increase in the disorder of social networks, group cohesion, and communication due to low retention levels of employees in the organisations. The companies that cannot retain their employees may affect economics result of the organisations and finally become the competitors for the organisation as well (Day 2000).

To survive in this present competitive business environment, it is important for organisations to retain their committed employees because of the high cost of recruitment and selection (Pfeffer 1998), the lag and productivity loss during the assimilation period (Davies 2001), the likely loss of business opportunity (Walker 2001), poor customer relationship (Clarke 2001; Messmer 2000), and hidden cost of loss productivity (Das 2002). According to Storey (1992), employers seek to treat employees as valued assets who can be a source of competitive advantage through their commitment, trust, adaptability and high quality skills and knowledge. This empowerment ultimately increases the competitiveness of the business. Arthur (1994) concluded that by using commitment strategies, organizations had significantly higher performance and lower turnover, compared to those using control strategies.

According to Beck and Wilson (2001), although numerous researches have been studied about organizational commitment, but there is a doubt on how the factors purported to be associated with it contribute to its development or how these organizational factors can be managed to promote the development of organizational commitment. It is now widely accepted that retention factors, and trust within the organization are some of the organizational factors that have been associated with organizational commitment (Meyer, Allen 1997; Damayanti 2009). Commitment has also been related to valuable outcomes for both the employee and employer. Benefits for the employee may include improved well-being from, for example, increased moral strength and reduced stress to increased organizational commitment (Mayer, Allen 1997). Benefits for the employer from increased commitment can include decreased absenteeism, lateness and turnover, as well as improved productivity (Mathieu, Zajac 1990; Mayer, Allen 1997; Mowday 1998; Randall 1987). Nik Mutasim and Hizam (2002) studied commitment to profession and organization and tried to identify its conflicts or compatibility. This study suggested to conduct research on the concepts on other samples in Malaysia. Having the potential to product advantageous financial and psychological outcomes, organizational commitment is important for every type of organization. Interestingly not enough, or no study so far has examined knowledge workers' organizational commitment in Malaysia. Moreover, it is not clearly known what factors contribute to the organizational commitment of knowledge workers, especially IS/IT personnel in Malaysia.

The major challenges of all types of organizations across all management levels are retaining knowledge workers who have high competitive value (DeLong 2004; Frank, Finnegan, Taylor 2004; Jamrog 2004; Ready, Conger 2008; Somaya, Williamson 2008). According to Paul (2000) in this globalization era attracting and retaining highly skilled, independent, internationally marketable and mobile individuals are crucial for the organizations for its present and future success. In the changing world of work, the psy- 
chological contract between employer and employee has changed fundamentally (Lee 2001) and long term commitment to an organization is no longer expected by either party (Armstrong, Murlis 1998). Nowadays most of the organizations become increasingly dependent on knowledge workers. In an organizational life it is crucial to increase retention and decrease turnover and attract and retain key talents and has become more important for improving the competency level (Bussin 2002).

Commitment has been defined and measured in many ways. Researchers agreed that commitment can take different forms, and that it is a complex construct (Meyer, Allen, Smith 1993; Mottaz 1988). Researchers have devoted much attention to the matter of identifying the predictors of organizational commitment. Predictors of commitment have been studied, not merely to produce commitment as an end in itself, but as a means of linking commitment to desirable organizational outcomes such as improved attendance and improved performance (Mottaz 1988).

\section{Literature review}

\subsection{Definition of knowledge workers}

The review of the terms "knowledge", "knowledge work", "knowledge companies", "knowledge management" and "knowledge workers" has many implications. It leads to an understanding that organizations need to look after the valuable asset (i.e. knowledge) that their knowledge workers have. Drucker (1959) first used the term "knowledge worker" (KW) to mean a worker that works with intangible resources. Drucker (1994) defined KW as an employee who applied theoretical and analytical knowledge, acquired through formal education to develop new products or services (Ramirez, Nembhard 2004; Scott 2005). Some researchers argued that knowledge could also come from informal education such as experiences in specific areas or organizational knowledge (Nickols 2000). A knowledge worker is anyone who works for a living in the tasks of developing or using knowledge (SearchCRM.com. 2003). For example, a knowledge worker might be someone who used to work at any of the tasks of planning, acquiring, searching, analyzing, organizing, storing, programming, distributing, marketing, or otherwise contributing to the transformation and commerce of information and those (often the same people) who work for using the knowledge produced in this way.

In the local context of Malaysia, the Malaysian Development Corporation defines knowledge workers, cited by Nor et al. (2006) as, follows:

"A knowledge worker is an individual who possesses one of these qualifications: five or more years' of professional experience in multimedia/information and communication technology (ICT) business or in a field that is a heavy user of multimedia; a university degree (in any discipline) or a graduate diploma (multimedia/ICT) from a professional experience in multimedia; and a master degree or higher in any discipline."

Accordingly, all Malaysian workers who possess any higher qualification are considered by the government as knowledge workers, even when they do not continue to work in their own fields. In addition, the Malaysian definition of knowledge workers seems to focus on information technology, though it is known that information technology is only 
a tool to enable knowledge workers to perform their tasks faster and more efficiently (Davenport, Prusak 2000; Crayson, O’Dell 1998; Kermally 2002). By looking at this definition, Malaysia will have more than enough knowledge workers in the future, as there will be many university graduates with diverse backgrounds who will finish their schooling by the year 2020 (Malaysia 2001: 104-106).

\subsection{Factors affecting organizational commitment}

Literature on retention of employees reported that many organizations faced the imperative task of retaining their employees as well as making sure that their employees remain loyal and committed to their organization (Brown, Yoshioka 2003; Lazarova, Caliguiuri 2001). Primary concerns of retaining employees with their current organization are the factors that causes retention. In this current trend of organization like high technology company, most important and interesting issue and important question for employers and researchers is to retain their valuable and committed workers. Nowadays, high technology company is struggling to retain their valuable technical employees due to the shortage of skilled and experienced employees and the aggressive recruitment tactics of others in the high technology arena. Thus, here employers seek to treat employees as valued assets who can be a source of competitive advantage through their commitment, trust, adaptability and high quality skills and knowledge (Storey 1992). This empowerment should increase the competitiveness of the business. Empirical study by Igbaria and Greenhaus (1992), and Igbaria and Guimaraes (1999) reported that organizational commitment would play an important role for the IT personnel.

"Is retention of employee important?" and "is employee commitment also important?", these two research questions are arising when researchers conduct research in organisational behaviour. Retaining skilled and technical staff and keeping staff loyal and committed to the organisation is a difficult task for an organisation (Brown, Yoshioka 2003; Lazarova, Caliguiuri 2001). Researchers and employers find that this is very interesting issue in the present trend of organization like high technology company. Nowadays, High Technology Companies are struggling to retain their valuable technical employees due to the shortage of experienced candidates and the aggressive recruitment tactics of the others in the high technology arena (Damayanty 2009). So, most of the employers seek to treat technical employees as valued assets who can be a source of competitive advantage through their commitment, trust, adaptability and high quality skills and knowledge (Storey 1992). This empowerment will increase the competitiveness of the business (Damayanty 2009).

On the other hand, to have committed employees in the organization and to increase retention of their employees, the employer needs to identify the factors those significantly influence organizational commitment. Coff (1996) states that the main reasons of tendency of leaving outstanding employees are dissatisfaction, underpayment, demotivation, not providing training facilities for development and do not provide opportunity to get promotion. When companies try to retain these employees, they may demand higher wages, may not comply with organizational practices, and may not interact well with their co-workers or may not comply with their supervisor's directions. According 
to Dawley et al. (2007), strong (and weak) supervisor's support has shown to affect employees in several ways. Strong supervisor's support is one of the key elements of retaining employee in the job. Study by Munn et al. (1996) found that supervisor's support was the best predictor of job satisfaction and intention to quit the company. Similarly, Hatton and Emerson (1998) found that low levels of supervisor's support were associated with increased turnover.

Job characteristic is one of the most important factors having beneficial effect on organizational commitment. Hackman and Oldham (1976) stated that five core characteristics, such as skill variety, task significance, task identity, autonomy and feedback are major characteristics that motivate employees in the job. Allen et al. (2004) found that all the job characteristics have significant effects on organizational commitment. The degree of autonomy was found to be positively related to all three measures of organizational commitment (Johns 2005). According to Marsh and Mannari (1977), the higher level of job autonomy that the individual possesses, correlates negatively with turnover. These diverse findings make it interesting to see whether different job characteristics are significantly correlated with organizational commitment of knowledge workers in Malaysia.

Ahmad and Bakar (2003) found that training of employees i.e. availability of training, support for training, motivation to learn, training environment, perceived benefits of training were all significantly correlated with organizational commitment. Nik Mutasim, Shahid and Alam (2011) study also confirmed significant relationship between training and organizational commitment. A number of researchers argued that compensation has been viewed as one of the most interesting variable to be examined in the context of employees' behavior. For example, Nik Mutasim et al. (2011), Barber and Bretz Jr. (2000) and Chiu et al. (2002) studies have also explored the relationship between compensation elements (e.g. money and benefits) and the attraction, retention and motivation of employees, and compensation contributes to retain and get the employees involve the employees in the success of the organization (Hiltrop 1999; Mc Mahan et al. 1998). In contrast, work life policies are considered as having a strong relationship with organizational commitment (Dockel 2003).

\subsection{Theoretical framework and hypotheses}

In this study, seven factors have been identified, based on past research, as retention factors which are influencing affective organizational commitment namely compensation, career opportunity, training and development, supervisor's support, job autonomy, work life policies and skill varieties. The first factor to be investigated in this study is compensation. Hoyt and Gerdloff (1999) reported that compensation offers an opportunity for security, autonomy, recognition and improvement of self-worth. These increased feeling of self worth and importance should lead to affective commitment (Mathieu, Zajac 1990). Igbaria and Greenhaus (1992) research has proven that salary is positively related to organizational commitment. Schaubroeck et al. (1994) argued that perceptions of fairness in compensation had been shown to be positively linked with affective organizational commitment. 
Tendency towards blocking high technology professionals has ultimate results in the form of less commitment to their employers. Igbaria and Greenhaus (1991) found that employees whose career orientations were compatible with their job settings reported high job satisfaction, high career satisfaction and strong commitment to their organizations and low intention to leave the organization.

Employee training is intended to provide an opportunity for advancement and might be perceived that "the organization values them and bolster their sense of self worth, therefore building a stronger affective commitment" (Meyer, Allen 1997). Training, if put to use in the job, should increase affective organizational commitment through its link to increase job scope. This response can be a function of closer psychological attachment to the organization and its goal (McElory 2001). Pare et al. (2001) found training positively related to affective commitment.

Eby et al. (1999) indicated that a work environment is characterized by participation in important work related decisions, supervisory feedback and support and rewards, that are perceived as fair and equitable (Bandura 1986). These provide individuals with the chance to make a difference in terms of the job, try out new skills, exercise discretion and receive feedback on their performance. These work conditions are expected to increase individuals' intrinsic motivation by providing affirmation that their efforts are valued (Thomas, Valthouse 1990). Pare et al. (2001) indicated that recognition from the supervisor was found to be related to affective commitment. The reason for this might be that high technology employees explore new solutions and get feedback and recognition from supervisors, which ultimately increases their feelings of self-worth, not their obligation to stay at the company.

In the research model, job autonomy is conceptualized as direct relationship between affective organizational commitments. Brown and Peterson (1994), Niehoff et al. (1990) and Westman (1992) argued that several streams of research suggest a positive relationship between job autonomy and employee affective responses, such as job satisfaction and organizational commitment.

Gover and Crooker (1995) empirically tested the effects of work and family benefits on organizational commitment. According to them benefits include parental leave, flexible schedules, childcare assistance and childcare information. Employees who had access to work/life policies showed significantly greater organizational commitment and expressed significantly lower intention to quit their jobs. Work/life policies were reported by Pare et al. (2001) to be related to affective commitment.

Mathieu and Zajac (1990) found a positive correlation between skill variety and organizational commitment. One way that individuals may develop a sense of competency is by working in a job with high skill variety (Hackman, Oldham 1975, 1976). Skill variety relates to feelings of belonging and sense of attachment to the organization (Meyer, Allen 1991). According to Mathieu and Zajac (1990) skill variety is one of the factors which influence affective organizational commitment. 


\subsection{Hypotheses of the study}

The general research aim of this paper is to understand the relationship between various retention factors influencing affective organizational commitment. This objective was addressed through quantitative analysis. Seven hypotheses were derived to examine the objective of this study:

H1: There will be positive relationship between compensation and affective commitment.

H2: There will be positive relationship between career opportunity and affective commitment.

H3: There will be positive relationship between training and development and affective commitment.

H4: There will be positive relationship between supervisor's support and affective commitment.

H5: There will be positive relationship between job autonomy and affective commitment.

H6: There will be positive relationship between work life policies and affective commitment.

H7: There will be positive relationship between skill varieties and affective commitment.

\section{Reliability}

The measurement of reliability provides consistency in the measurement of variables. Zhang et al. (2000) argued that internal consistency reliability is the most commonly used psychometric which is measured assessing survey instrument and scales. It is stated by Kim and Cha (2002) that Cronbach alpha is the basic formula for determining the reliability based on internal consistency. Table 1 shows the number of items comprising each scale. The reliability reported by Moore and Benbasat (1991) for the scale and Cronbach's alpha for scale reliability is obtained for our sample. The alpha values for

Table 1. Reliability analysis

\begin{tabular}{llc}
\hline \multicolumn{1}{c}{ Variables } & Items & Coefficient Alpha \\
\hline Affective Commitment & 6 items & .909 \\
\hline Compensation & 6 items & .937 \\
\hline Career Opportunity & 6 items & .917 \\
\hline Training \& Development & 6 items & .936 \\
\hline Supervisor Support & 7 items & .924 \\
\hline Job Autonomy & 4 items & .808 \\
\hline Work/life policies & 6 items & .907 \\
\hline Skill Varieties & 6 items & .905 \\
\hline
\end{tabular}


affective commitment yields reliability co-efficient of 0.909 . This value far exceeds the minimum standard of 0.7 set by Nunnally (1978). Similarly, the six statements measure for compensations generates a Cronbach Alpha value of 0.937 , highlighting an internal consistency in the measurement.

The values of alpha obtained for career opportunity is 0.917 , which suggests that scale is reliable for use in this study. The measures for training \& development, supervisor's support, job autonomy and work/life policies gave respective Cronbach Alpha values of $0.936,0.924,0.808$ and 0.907 which are also supportive. The high reliability coefficient for skill varieties $(0.905)$ indicates high internal consistency among its statements. This is consistent with reports by Nunnally (1978).

\section{Multicollinearity}

Non-existence of Multicollinearity is another important assumption to be examined. The multicollinearity is a question of degree. Tolerance test was carried out for each independent variables by selecting Collinearity diagnostics in SPSS as recommended by Norusis (1994). None of the tolerances for each of the independent variables is, 01 or less than 0.01 (Table 2). The results of collinearity test show that the data are not seriously multicollinear.

Table 2. Test of collinearity

\begin{tabular}{lcc}
\hline \multicolumn{1}{c}{ Variable } & Tolerance & VIF \\
\hline Compensation & .478 & 2.093 \\
\hline Career Opportunity & .571 & 1.752 \\
\hline Training \& Development & .593 & 1.687 \\
\hline Supervisor Support & .468 & 2.135 \\
\hline Job Autonomy & .621 & 1.611 \\
\hline Work/life policies & .447 & 2.238 \\
\hline Skill Varieties & .425 & 2.355 \\
\hline Trust & .610 & 1.640 \\
\hline
\end{tabular}

Another important assumption which is evaluated is multicollinearity. To test multicollinearity, Kleinbaum et al. (1988) suggested computing as the Variance Inflation Factor (VIF) for each independent variable. They also suggested that, as a rule of thumb, if the VIF of a variable exceeds 10 , that variable is said to be highly collinear and will pose a problem to regression analysis. This condition is adopted to check multicollinearity among the independent variables. Table 2 shows the variables together with their respective VIF values. From the table, all of the VIF values are well below 10, ranging from 2.238 to 7.255 . Therefore, there is really no problem of multicollinearity. The acceptable Durbin-Watson range is between 1.5 and 2.5. In this analysis Durbin-Watson value of 2.033 , which is between the acceptable ranges, shows that there were no auto correlation problems in the data used in this research. Thus, the measures selected for assessing independent variables in this study do not reach levels indicated for multicollinearity. 
To test the multicollinearity, the correlation matrix of the variables was studied to identify the occurrence of multicollinearity. The correlation coefficient is a measure of the closeness of the relationships or association between independent and dependent variables (Hair et al. 1995). Multicollinearity problem exists when the independent variables are too highly correlated (Kothari 1995). For the interval scale of the nature of the variables in this study Pearson correlation is appropriate (Sekaran 2000). The correlation also ensures that the Pearson's $r$ between each pair of independent variables does not exceed 0.85 . The results indicate that none of the squared correlations was close to 0.85 to suggest a problem with multicollinearity among the research variables (Hair et al. 1995). All the relationships are related to the expected direction and were significantly correlated. Therefore, there is no evidence of significant multicollinearity among the research variables.

\section{Hypotheses relating to retention factors and affective commitment}

The results show that the multiple regression coefficients $(R)$ of the seven independent variables and affective commitment $R$ was .716 and R Square was .512. Table 3 shows the aggregate effect of regression analysis.

Table 3. Aggregate effect of the seven independent variables on affective commitment

\begin{tabular}{cccccc}
\hline $\mathrm{R}$ & $\mathrm{R}$ Square & Adjusted R Square & Std. Error of the Estimate & F Value & Sig. F \\
\hline .716 & .512 & .504 & .42735 & 62.126 & .000 \\
\hline
\end{tabular}

The results suggest that the seven factors are considered in the mode of account for 51 per cent (R Square) of the variation in knowledge workers working in the IT Malaysian IT sectors on affective organizational commitment. This is significantly explained by the groups of seven independent variables, as shown by the large $F$ value of 62.126 $(p<.000)$. Therefore, there is evidence that these seven independent variables significantly affect organizational commitment by the knowledge workers in Malaysia.

Table 4. Influence of independent variables on affective commitment

\begin{tabular}{lcccc}
\hline \multicolumn{1}{c}{ Variable } & \multicolumn{2}{c}{ Standardized Coefficients } & $t$ & Sig. \\
\hline & Beta & Standard Error & & \\
\hline Compensation & .195 & .069 & 3.317 & .001 \\
\hline Career Opportunity & .157 & .050 & 2.914 & .005 \\
\hline Training \& Development & .223 & .050 & 4.230 & .001 \\
\hline Supervisor Support & .066 & .087 & 1.106 & .270 \\
\hline Job Autonomy & .146 & .050 & 2.825 & .005 \\
\hline Work/life policies & .181 & .058 & 2.914 & .005 \\
\hline Skill Varieties & .092 & .071 & 1.486 & .138 \\
\hline
\end{tabular}

(Standard Error in Parentheses) 
Retention factors in the conceptual model were derived through the literature review. This study contends that retention factors have direct and positive relationship with affective commitment. The influences of the retention factors on affective commitment were explored through hypotheses $\mathrm{H} 1, \mathrm{H} 2, \mathrm{H} 3, \mathrm{H} 4, \mathrm{H} 5, \mathrm{H} 6$ and $\mathrm{H} 7$. The results of the hypotheses testing are discussed in the following section and the results are shown in Table 4.

\subsection{Hypothesis H1}

Hypothesis H1 investigated the positive influence on affective organizational commitment of knowledge workers in Malaysia. The statistical evidence supported this link and $\mathrm{H} 1$ was accepted. The result is statistically significant at 0.01 level. The findings are consistent with the results from studies by Nawab and Bhatti (2011) and Schaubroeck et al. (1994) who reported on the positive influence of compensation on affective commitment. In addition, the result aligns with the findings of studies like Igbaria and Greenhaus (1992) that report on the significant influence of salary on affective commitment. Based on this positive coefficient of the variable of compensation effects on affective commitment, this study concludes that there is a positive relationship of compensation on affective commitment. Thus the first null hypothesis of this study is rejected and alternative hypothesis of this study is accepted.

The practical implication is that greater emphasis should be placed on compensation for knowledge workers among the IT staffs in Malaysia. Information and communication industries should understand that compensation offers an opportunity for security, autonomy, recognition and improved self worth (Hoyt, Gerdloff 1999). The message communicated among the staff must be accurate, consistent and relevant to convince people working in the organizations. Furthermore, to reassure organizations also could provide the clear information about the compensation policies to their staff.

\subsection{Hypothesis $\mathbf{H 2}$}

The H2 investigated the positive influence of career opportunity on affective commitment. The quantitative findings support the hypothesis and are also proven to be statistically significant at 0.01 level (t-value 2.914, see Table 4). This result is in line with previous results from other human resources studies (Puah, Ananthram 2006; Johns 2005; Zabusky, Barley 1996). The findings reinforce field study data which support the link between career opportunity and affective commitment.

The implication is that companies that have high career opportunities for experience in many different areas, staffs are more likely committed to their organization. According to Schein (1978) in practice, companies have become less paternalistic and encourage more self-reliance from employees. On the other hand, careers are being reconceptualized away from position oriented job histories and toward a set of experience and skill accumulated through changing roles and non-traditional paths (Applegate, Elam 1992; Zabusky, Barley 1996). 


\subsection{Hypothesis $\mathrm{H3}$}

This study posited through hypothesis H3 that training and development of the knowledge workers would have positive influence on affective commitment. The results of hypothesis testing indicated that there is significant statistical evidence to support the positive influence of training and development on affective commitment and has proven to be statistically significant at 0.01 level (t-value 4.230, see Table 4). The findings are consistent with previous results from HRM practices studies by Barlett (2001), Ahmad and Bakar (2003), Al-Emadi and Marquardt (2007). Newman et al. (2011) study found a strong relationship between perceived availability of training and organizational commitment. The result is also in accordance with the study on social exchange theory (Settoon et al. 1996).

The practical implication of this finding is that IT firms, as the major suppliers of knowledge workers could play a greater role to improve employees' training and development opportunities and also to meet their employees' expectations in the area of organizational development. The members of professional bodies that are involved in human resource development in Malaysia are able to learn about training requirements for the knowledge workers and then will be involved in the human resource development in Malaysia. On the other hand IT organizations need to ensure that their workers are actively participating in the training and development program provided by the internal body of the organization or outside the organization in Malaysia or abroad. More importantly, organizations need to remember that the key consideration in organizing the training development program is to ensure quality and relevancy of the staff development as well as organization development. The organization might do this by publicizing training opportunities more widely and providing assistance to managers to explain the availability of training opportunities to their subordinates.

\subsection{Hypothesis $\mathrm{H} 4$}

The construct supervisor's support is considered in the analysis to examine whether exerts positive and significant influence on affective commitment or not. Supervisor's support was not found to be significantly related to affective commitment. It appears that the $t$-value of the variable is less than the critical $t$ - value indicating that there is no significant influence on affective commitment in the organization, at critical t-value of 1.96 for the sample size of 296 , and a $95 \%$ confidence level. This means that the results of hypothesis testing did not statistically support this link and H4a was rejected. The lack of support for $\mathrm{H} 4$ is in contrast with previous studies of Casper and Harris (2010), Cohen and Willis (1985), Viswesvaran et al. (1999). One possible explanation for the rejection of the hypothesis is that supervisor's support and organizational commitment is an Anglo American culture, so it may vary differently in different cultures (Glazer 2006). This orientation in Malaysia may not be important because the role played by the supervisor in Malaysia are not helping the people to work in the organizations.

Another possible explanation is that Malaysia is one of the multicultural countries where different races are working in the same organization. So if the supervisor is from different race, they feel to work independently. 


\subsection{Hypothesis $\mathrm{H5}$}

According to Sims et al. (1976) job autonomy is defined as the degree to which employees are allowed freedom, independence and discretionary powers when performing their tasks and responsibilities. If knowledge worker get more autonomy in their job such as what, when and how to do work, he or she would feel a sense of responsibility for the tasks and responsibilities they are entrusted with (Karim 2010). The studies of Price and Mueller (1997), Gregersen and Black (1996), Newman (1993) found that there was a statistically significant relationship between job autonomy and organizational commitment. Therefore, hypothesis H5 examined the positive influence of job autonomy and organizational commitment. The quantitative findings confirmed the significant influence of job autonomy on affective organizational commitment.

The business implication of this finding is that the company board of directors needs to provide autonomy to their knowledge workers to work properly. In the organizations when job autonomy is high, the workers will view their work outcomes in terms of their own efforts, initiatives and decisions, rather than because of instruction of the supervisor or as the result of procedure (Marx 1996).

\subsection{Hypothesis H6}

The present study, in hypothesis H6, proposed that work life policies would positively influence affective organizational commitment. Results from data analysis reveals that the direction of the influence is as predicted and t-value is significant at 0.01 level ( $\mathrm{t}$-value, 2.914). The finding is consistent with results from literature review, which supports work/life policies influence affective commitment (Merrick 1998; Grover, Crooker 1995; Pare et al. 2001).

Recent studies have attempted to examine the significance of work life policies in the organization (Lilley 2004). Due to the increased female labour force participation and aged dependents are also increasing higher proportion of employees who have family responsibilities in any developed as well as developing countries (Hall, Liddicoat 2005). High levels of organizational commitment occur if the employees perceive the planning and implement organizational decisions that are fair for all although there is work-life conflict occurs. Cocket (2003) study also asserted that work life policies have a strong and significant relationship with organizational commitment.

Malaysia is one of the developing countries in AEAN region. Work/life policies for the knowledge workers differ based on the sectors they work in. Due to the bureaucratic nature of the government sectors anybody working in the public sectors feels more reluctant compared to private organizations. However in private sectors organizations are totally different. The people working in the private organization need to work 40-50 hours on average in a week. Frequent late sittings are common for the people working in the private sectors and ultimately this will create work life conflict for the employees. This study also confirms that on average all the knowledge workers have to work more than 45 hours in a week. This study collected data from the knowledge workers of private organizations in Malaysia. 


\subsection{Hypothesis $\mathrm{H7}$}

The final retention factor is the skill variety. Hypothesis $\mathrm{H} 7$ posited that the skill variety would positively influence affective organizational commitment. The result of the statistical analysis reveals that although the direction of the influence is as predicted but it did not support the proposed hypothesis. It appears that the $t$-value of the variable is less than the critical $t$-value indicating that there is no significant influence of skill varieties on affective organizational commitment, at critical $t$-value of 1.96 for the sample size of 296 , and a $95 \%$ confidence level.

This study is not consistent with previous findings from Hackman and Oldham's (1975) theory. This study also contradicts the results of Mathieu and Zajac (1990). The previous study also found low or medium positive correlation between skill variety and organizational commitment. According to Mayer and Allen (1991), skill variety relates to the feelings of belonging and sense of attachment to the organization.

\section{Research limitations}

The first limitation of this study is that the cultural, institutional, economic and political environment, which is distinctive and unique in Malaysia, may restrict the generalisation of the results (Teo et al. 2003). Nevertheless, this lack of generality may not be as severe because Malaysia being a cosmopolitan country has attracted numerous multinational companies that have been represented in the study sample. Nevertheless, cross-country studies could provide further information on the applicability of this model under different cultural, institutional, economic and political conditions.

The second limitation is that the sample is limited to software companies due to time and financial constraints. There is evidence that the knowledge workers' commitment is ubiquitous regardless of company size. Therefore, there is still a need to investigate the lack of commitment in other companies in Malaysia.

This study mainly focuses on the relationship between retention factors and affective and continuance commitment. Therefore the scope of this study is to study only retention factors only. For future research, other factors such as personality traits of the employees, age, gender, tenure and environmental characteristics etc. should be investigated.

The respondents' self-ratings might not have been reflected their true perceptions of questionnaire items and therefore, the survey data might have some biases. Moreover, social disability bias (consciously and unconsciously has driven the respondents to create a favourable impression) acquiescence bias (the respondents tend to agree with all questions), and deliberate falsification are common types of respondent errors in survey studies (Zikmund 2000), which are limitations of this study.

It was very difficult to get primary as well as secondary data from the private sectors in Malaysia. Getting the respondents to participate in the structured interviews was quite difficult. However this limitation was overcome by making appointment with respective managers with the help of my relatives and friends. 


\section{Future research direction}

The limitations of the study imply the need for future research. The lack of generality due to the cultural, institutional, economic and political environment in Malaysia envisages the need for cross-country studies, which would provide future applicability of the conceptual model under differing political, economic and cultural conditions.

This study collected data from knowledge workers, defined earlier in this research from only software companies in Malaysia. Although the justification for the use of knowledge workers of the software industry is strong, future research could interview and survey other significant respondents. For example, company supporting staff, other top management staffs that play a vital role in the final organizational decision-making could be the samples. In addition, the use of multiple respondents form each organization would decrease potential response bias.

Many changes will arise in future; because an advancement of information technology in Malaysia is certain to continue, especially in the IT based companies like SMEs. Therefore, the government or the ministry of Human Resources needs to examine the needs of knowledge workers' commitment found in this study. Those who are not committed knowledge workers will ultimately move to other organizations.

The present study has used primary data, which was so far limited in sample size compared to the total population of the study area, and the limitation has been due to time constrain as well as resources. Hence determination of the sample size has been made in accordance with resource availability. It is recognized that the larger the sample sizes the more precious the results and findings will be. Accordingly, there might be a scope for getting different results and assumptions on the factors which affect EC adoption in the business.

\section{Conclusions}

As for conclusion, this study has achieved its main objective, which is to study the effect of retention factors affecting affective organizational commitment among knowledge workers in Malaysia. Furthermore, the analysis indicates that in general the retention factors have some effects on the affective organizational commitment even though two of the factors (supervisor support and skill varieties) do not show any support.

\section{Acknowledgement}

The authors thank anonymous reviewers and managing editor of the Journal of Business Economics and Management for their helpful comments.

\section{References}

Abbasi, S.; Hollman, K. 2000. Turnover: the real bottom line, Public Personnel Management 29: 333-342 [online], [cited 11 July 2007]. Available from Internet: www.ipmahr.org/newsfiles/2000 3 abbasi.pdf

Ahmad, K. Z.; Bakar, R. A. 2003. The association between training and organizational commit- 
ment among white-collar workers in Malaysia, International Journal of Training and Development 7(3): 166-185. http://dx.doi.org/10.1111/1468-2419.00179

Al-Emadi, M. A. S.; Marquardt, M. J. 2007. Relationship between employees beliefs regarding training benefits and employees organizational commitment in a petroleum company in the state of Qatar, International Journal of Training and Development 11(1): 49-70.

http://dx.doi.org/10.1111/j.1468-2419.2007.00269.x

Allen, T. D.; Eby, L. T.; Poteet, M. L.; Lentz, E.; Lima, L. 2004. Career benefits associated with mentoring for protégés: a meta-analysis, Journal of Applied Psychology 89(1): 127-136.

http://dx.doi.org/10.1037/0021-9010.89.1.127

Applegate, L. M.; Elam, J. J. 1992. New information systems leaders: a changing role in a changing world, MIS Quarterly 16(4): 469-491. http://dx.doi.org/10.2307/249732

Arkin, A. 1997. No place like work, People Management 3(25): 22-26.

Armstrong, M.; Murlis, H. 1998. Reward Management. London: Biddles Ltd.

Arthur, J. B. 1994. Effects of human resources systems on manufacturing performance and turnover, Academy of Management Journal 37: 670-687. http://dx.doi.org/10.2307/256705

Bandura, A. 1986. Social foundation of through and action: a social-cognitive view. Englewood Cliffs, NJ: Prentice-Hall.

Barber, A. E.; Bretz, R. D. Jr. 2000. Compensation, attraction and retention, in S. L. Rynes, B. Gerhart (Eds.). Compensations. Francisco, CA: Jossey-Bass, 32-60.

Barlett, K. R. 2001. The relationship between training and organizational commitment: a study in the health care field, Human Resource Development Quarterly 12(4): 335-352.

http://dx.doi.org/10.1002/hrdq.1001

Beck, K.; Wilson, C. 2001. Have we studied, should we study, can we study the development of commitment? Methodological issues and developmental study of work-related commitment, Human Resource Management Review 11: 257-278.

http://dx.doi.org/10.1016/S1053-4822(00)00051-6

Brown, S. P.; Peterson, R. A. 1994. The effect of effort on sales performance and job satisfaction, Journal of Marketing 58: 70-80. http://dx.doi.org/10.2307/1252270

Brown, W. A.; Yoshioka, C. F. 2003. Mission attachment and satisfaction as factors in employee retention, Nonprofit Management and Leadership 14(2): 5-18. http://dx.doi.org/10.1002/nml.18

Bussin, M. 2002. Retention strategies: remuneration answers. Johannesburg: Knowledge Resources.

Casper, W. J.; Harris, C. M. 2010. Work-life benefits and organizational attachment: self-interest utility and signaling models, Journal of Vocational Behavior 72(1): 95-109.

http://dx.doi.org/10.1016/j.jvb.2007.10.015

Chiu, K. R.; Luk, V. W.; Tang, T. L. 2002. Retaining and motivating employees, compensation preferences in Hong Kong and China, Personnel Rev. 31(4): 4024-4031.

http://dx.doi.org/10.1108/00483480210430346

Clarke, K. F. 2001. What businesses are doing to attract and retain employee-becoming an employer of choice, Employee Benefits Journal 26(1): 21-24.

Cocket, W. H. 2003. Employee attitude and employee performance, Psychological Bulletin 5: 396-424.

Coff, R. W. 1996. Human assets and management Di Lemmas: coping with hazards on the road to resource-based theory, Academy of Management Journal 22: 374-402.

Cohen, S.; Willis, T. A. 1985. Stress, social support, and the buffering hypothesis, Psychological Bulletin 98(2): 310-357. http://dx.doi.org/10.1037/0033-2909.98.2.310 
Crayson, J.; O’Dell, C. 1998. If only we knew what we know: identification and transfer of internal best practices, California Management Review 40(3): 154-165.

http://dx.doi.org/10.2307/41165948

Damayanty, N. 2009. The Relationship between Retention Factors and Career Commitment [online], [cited 17 May 2011]. Available from Internet: http://scholar.googleusercontent.com/schola r?q=cache:S104qAO58dYJ:scholar.google.com/\&hl=en\&as_sdt=0,5\&as_vis=1

Das, H. 2002. The four faces of pay: an investigation into how Canadian managers view pay, International Journal of Commerce \& Management 12: 18-41. http://dx.doi.org/10.1108/eb047435

Davenport, T. H.; Prusak, L. 2000. Working knowledge: how organizations manage what they know. $2^{\text {nd }}$ ed. Boston: Harvard Business School Press.

Davies, R. 2001. How to boost staff retention, People Management 7: 54-56.

Dawley, D. D.; Stephens, R. D.; Stephens, D. B. 2007. Dimensionality of organizational commitment in volunteer workers: chamber of commerce board members and role fulfillment, Journal of Vocational Behavior 67(3): 511-525. http://dx.doi.org/10.1016/j.jvb.2004.09.001

Day, C. 2000. Stories of change and professional development: the costs of commitment, in C. Day, A. Fernandez, T. Hauge, J. Moller (Eds.). The life and works of teachers: international perspectives in changing times. London: Falmer Press, 109-129.

DeLong, D. W. 2004. Lost knowledge: confronting the threat of an aging workforce. New York: Oxford University Press.

Dockel, A. 2003. The effects of retention factors on organizational commitment an investigation of high technology employees, Faculty of Economics and Management Science 1-161.

Drucker, P. F. 1994. The age of social transformation, The Atlantic Monthly 274(5): 53-80.

Drucker, P. F. 1959. Landmarks of tomorrow: a report on the new post-modern world. New York: Oxford University.

Eby, L. T.; Freeman, D. M.; Rush, M. C.; Lance, C. E. 1999. Motivational bases of affective organizational commitment: a partial test of an integrative theoretical theoretical model, Journal of Occupational \& Organizational Psychology 72(4): 463-484.

http://dx.doi.org/10.1348/096317999166798

Frank, F. D.; Finnegan, R. P.; Taylor, C. R. 2004. The race for talent: retaining and engaging workers in the $21^{\text {st }}$ century, Human Resource Planning 27(3): 12-25.

Glazer, S. 2006. Social support across cultures, International Journal of Intercultural Relations 30: 605-622. http://dx.doi.org/10.1016/j.ij Qintrel.2005.01.013

Gregersen, H. B.; Black, J. S. 1996. Multiple commitments upon repatriation: the Japanese experience, Journal of Management 22: 209-229.

Grover, S. L.; Crooker, K. J. 1995. Who appreciates family-responsive human resources policies: the impact of family-friendly policies on the organizational attachment of parent and non-parents, Personnel Psychology 48(2): 271-289. http://dx.doi.org/10.1111/j.1744-6570.1995.tb01757.x

Hackman, J. R.; Oldham, G. R. 1975. The development of the job Diagnostic Survey, Journal of Applied Psychology 60(2): 159-170. http://dx.doi.org/10.1037/h0076546

Hackman, J. R.; Oldham, G. R. 1976. Motivation through the design of work: tests of a theory, Organizational Behaviour and Human Performance 16: 250-279.

http://dx.doi.org/10.1016/0030-5073(76)90016-7

Hair, J.; Anderson, R.; Tatham, R.; Black, W. 1995. Multivariate data analysis with readings. $4^{\text {th }}$ ed. New Jersey: Prentic-Hall.

Hall, L.; Liddicoat, L. 2005. Challenges to developing effective family friendly work practices: findings from New Zealand, Research and Practice in Human Resource Management 13(1): 1-17. 
Hatton, C.; Emerson, E.1998. Brief report: organizational predictors of actual staff turnover in a service for people with multiple disabilities, Journal of Applied Research in Intellectual Disabilities 11: 167-171. http://dx.doi.org/10.1111/j.1468-3148.1998.tb00058.x

Hiltrop, J. M. 1999. The quest for the best: human resource practices to attract and retain talent, European Management Journal 17: 422-430. http://dx.doi.org/10.1016/S0263-2373(99)00022-5

Hoyt, J.; Gerdloff, E. A. 1999. Organizational environment, changing economic conditions and the effective supervision of technical personnel: a management challenge, Journal of High Technology Management Research 10(2): 275-294. http://dx.doi.org/10.1016/S1047-8310(99)00014-0 Igbaria, M.; Guimaraes, J. H. 1999. Exploning differences in employee turnover intentions and its determinants among telecommiters and non-telecommuters, Journal of MIS 16(1): 147-164.

Igbaria, M.; Greenhaus, J. H. 1991. Career orientations of MIS employees: an empirical analysis, MIS Quarterly 15(2): 151-170. http://dx.doi.org/10.2307/249376

Igbaria, M.; Greenhaus, J. H. 1992. Determinants of MIS employees turnover intention: a structural equation model, Communication of the ACM 35(2): 35-49.

http://dx.doi.org/10.1145/129630.129631

Jamrog, J. 2004. The perfect storm: the future of retention and engagement, Human Resource Planning 27(3): 26-33.

Johns, R. 2005. Determinants of Organizational Commitment Among U.S Workers: Unpublished Master's Thesis. Duquesne University.

Karim, N. H. A. 2010. The impact of work related variables on librarians organization commitment and job satisfaction, Malaysian Journal of Library \& Information Science 15: 149-163.

Kermally, S. 2002. Effective knowledge management: a best practice blueprint. England: John Wiley \& Sons.

Kim, W. G.; Cha, Y. 2002. Antecedents and consequences of relationship quality in hotel industry, International Journal of Hospitality Management 21: 321-338.

http://dx.doi.org/10.1016/S0278-4319(02)00011-7

Kleinbaum, D. G.; Kupper, L. L.; Muller, K. E. 1988. Applied regression analysis and other multivariate methods. Boston: PWS.

Kothari, R. 1995. Rethinking development: in search of human alternatives. Delhi: Ajanta.

Lazarova, M.; Caliguiuri, P. M. 2001. Retaining repatriates: the role of organizational support practices, Journal of World Business 36: 389-401. http://dx.doi.org/10.1016/S1090-9516(01)00063-3

Lee, G. 2001. Towards a contingent model of key staff retention: the new psychological contract reconsidered, South African Journal of Business Management 32(1): 1-9.

Lilley, S. 2004. Whose Role is it Anyway? Implementing Family-friendly Workshop Practices in New Zealand: Research Project. University of Canterbury: Social Science Research Center.

Malaysia. 2001. Eighth Malaysia Plan 2001-2005. Kuala Lumpur: National Press.

Marsh, R. M.; Mannari, H. 1977. Organizational commitment and turnover. A prediction study, Administrative Science Quarterly 22: 57-75. http://dx.doi.org/10.2307/2391746

Marx, E. 1996. The influence of task and role characteristics on organizational commitment: Unpublished Dissertation. M. Com. Human Resources Management. University of Pretoria.

Mathieu, J. E.; Zajac, D. M. 1990. A review and met-analysis of the antecedents, correlates, and consequence of organizational commitment, Psychological Bulletin 108(2): 171-194.

http://dx.doi.org/10.1037/0033-2909.108.2.171

McElory, J. C. 2001. Managing workplace commitment by putting people first, Human Resources Management Review 11: 327-335. http://dx.doi.org/10.1016/S1053-4822(00)00054-1 
McMahan, G. C.; Bell, M.; Virick, M. 1998. Strategic human resource management: employee involvement, diversity, and international issues, Human Resource Management Review 8(3): 193-214. http://dx.doi.org/10.1016/S1053-4822(98)90002-X

Merrick, A. 1998. Companies goes extra miles to retain employees, $R \& D$ 40(10): 3-4.

Messmer, T. A. 2000. The emergence of human-wildlife conflict management: turning challenges into opportunities, International Biodeterioration \& Biodegradation 45(3-4): 97-102. http://dx.doi.org/10.1016/S0964-8305(00)00045-7

Meyer, J. P.; Allen, N. J. 1991. A tree-component conceptualization of organizational commitment, Human Resource Management Review 1: 61-89.

http://dx.doi.org/10.1016/1053-4822(91)90011-Z

Meyer, J. P.; Allen, N. J. 1997. Commitment in the workplace: theory, research, and application. Thousand Oaks, CA: Sage Publication.

Meyer, J. P.; Allen, N. J.; Smith, C. A. 1993. Commitment to organizations and occupations: extensions and test of a three-component conceptualization, Journal of Applied Psychology 78(4): 538-551. http://dx.doi.org/10.1037/0021-9010.78.4.538

Moore, G. C.; Benbasat, I. 1991. Development of an instrument to measure the perceptions of adopting an information technology innovation, Information Systems Research 2: 192-222.

http://dx.doi.org/10.1287/isre.2.3.192

Mottaz, C. J. 1988. Determinants of organizational commitment, Human Relations 41(6): 467482. http://dx.doi.org/10.1177/001872678804100604

Mowday, R. 1998. Reflections on the study and relevance of organizational commitment, Human Resource Management Review 8(4): 387-401. http://dx.doi.org/10.1016/S1053-4822(99)00006-6

Muchninsky, P. M. 1997. Psychology applied to work. $5^{\text {th }}$ ed. Pacific Grove, CA: Brooks/Cole Publising Co.

Munn, E.; Barber, C.; Fritz, J. 1996. Factors affecting the professional well being of child life specialists, Children's Health Care 25(2): 71-91. http://dx.doi.org/10.1207/s15326888chc2502_1

Nawab, S.; Bhatti, K. K. 2011. Influence of employee compensation on organizational commitment and job satisfaction: a case study of educational sector of Pakistan, International Journal of Business and Social Science 2(8): 25-32.

Newman, K. S. 1993. Declining fortunes: the withering of the american dream. New York, NY: Basic Books.

Newman, J.; Vries, D. H. de; Kanakuze, J. d'Arc; Ngendahimana, G. 2011. Workplace violence and gender discrimination in Rwanda's health workforce: increasing safety and gender equality, Human Resources for Health 9(19): 1-13.

Nickols, F. 2000. What is in the World of Work and Working: Some Implications of the Shift to Knowledge Work, The Knowledge Management Yearbook 2000-2001 [online], [cited 14 January 2012]. Available from Internet: http://books.google.com.my/books?id=5jQn8gBfPL8C\&pg=PA $3 \& \mathrm{lpg}=\mathrm{PA} 3 \& \mathrm{dq}=$ What $+\mathrm{is} \% \mathrm{E} 2 \% 80 \% 99+$ in + the+world + of + work+and+working:+some+implica tions + of + the + shift + to + knowledge + work \&source $=$ bl\&ots $=$ LpQBqU4b0U\&sig $=u T A 0 a c n z T h 0 X$ gx_0WzT1-MDKp0M\&hl=en\&sa=X\&ei=ZqRrUPW0J8SsrAf5y4Bo\&ved=0CCUQ6AEwAQ\# $\mathrm{v}=$ working $\% 3 \mathrm{~A} \% 20$ some $\% 20$ implications $\% 20$ of $\% 20$ the $\% 20$ shift $\% 20$ to $\% 20$ knowledge $\% 20$ work $\& \mathrm{f}=$ false

Niehoff, B. P.; Enz, C. A.; Grover, R. A. 1990. The impact of top-management actions on employee attitudes and receptions, Group \& Organization Studies 15(3): 337-352.

http://dx.doi.org/10.1177/105960119001500307

Nik Mutasim, N. A. R.; Hizam, M. H. 2002. Commitment to organization versus commitment to profession: conflict or compatibility?, Jurnal Pengurusan 21: 77-94. 
Nik Mutasim, N. A. R.; Shahid, S.; Alam, S. S. 2011. Relationship between Islamic HRM practices and employee commitment: an empirical study of Islamic banks in Bangladesh, Journal of Applied Sciences Research 7(8): 1269-1278.

Nor, N. M.; Laily, M.; Mohamad, P. N; Hussin, M. R. 2006. Knowledge Workers and Knowledge Management: Some Descriptive Evidence on the MSC Status Companies in Malaysia [online], [cited 29 March 2012]. Available from Internet: http://repo.uum.edu.my/2388/1/knowledge workers_and_knowledge_mgmt._some_descriptive_evidences_01.pdf

Norusis, M. L. 1994. SPSS Professional Statistics 6.1. Chicago: SPSS Inc.

Nunnally, J. C. 1978. Psychometric theory. $2^{\text {nd }}$ ed. New York: McGraw-Hill.

Pare, G., Tremblay, M.; Lalonde, P. 2001. The role of organizational commitment and citizenship behaviors in understanding relations between human resources practices and turnover intentions of IT personnel, Scientific Series \#2001s-24. CIRANO, Montreal, Canada.

Paul, D. (Ed.). 2000. The best companies to work for in SA. Cape Town: Zebra Press.

Pfeffer, J. 1998. The human equation: building profits by putting people first. Boston, MA: Harvard Business School Press.

Price, J. L.; Mueller, C. W. 1997. A casual model of turnover for nurses, Academy of Management Journal 24: 543-565. http://dx.doi.org/10.2307/255574

Puah, P.; Ananthram, S. 2006. Exploring the antecedents and outcomes of career development initiatives: empirical evidence from Singaporean employees, Research and Practice in Human Resource Management 14: 112-142.

Ramirez, Z. W.; Nembhard, D. A. 2004. Measuring knowledge worker productivity: a taxonomy, Journal of Intellectual Capital 5: 602-629. http://dx.doi.org/10.1108/14691930410567040

Randall, D. M. 1987. Commitment and the organization man revisited, Academy of Management Review 12: 460-471.

Ready, D. A.; Conger, J. A. 2008. How to fill the talent gap: global companies face a perfect storm when it comes to finding the employees they need, The Wall Street Journal Online September 15:R1 [cited 29 May 2008]. Available from Internet: http://online.wsj.com/public/ article_print/SB118841695428712511.html.

Schaubroeck, J.; May, D. R.; Brown, F. W. 1994. Procedural justice explanations and employee reactions to economic hardship: a field experiment, Journal of Applied Psychology 79: 455-460. http://dx.doi.org/10.1037/0021-9010.79.3.455

Schein, E. H. 1978. Career dynamics: matching individual and organisational needs. Reading: Addison-Wesley.

Scott, P. B. 2005. Knowledge workers: social task and semantic network analysis, Corporate Communications: An International Journal 10(3): 257-277.

SearchCRM. 2003. Knowledge Worker Definitions [online], [cited 13 January 2012]. Available from Internet: http://searchcrm.techtarget.com/

Sekaran, U. 2000. Research methods for business: a skills building approach. $3^{\text {rd }}$ ed. New York: John Wiley \& Sons.

Settoon, R. P.; Bennett, N.; Liden, R. C. 1996. Social exchange in organizations: perceived organizational support, leader-member exchange, and employee reciprocity, Journal of Applied Psychology 81: 219-227. http://dx.doi.org/10.1037/0021-9010.81.3.219

Sighter, K. W.; Adams, J. S. 1999. Different between stayers and leavers among part-time workers, Journal of Management Issues 11: 110-125.

Sims, H. P.; Szilagyi, A. D.; Keller, R. T. 1976. The measurement of job characteristics, Academy of Management Journal 19(2): 195-212. http://dx.doi.org/10.2307/255772 
Somaya, D.; Williamson, I. O. 2008. Rethinking the war for talent, MIT Sloan Management Review 49(4): 29-34.

Storey, J. 1992. Developments in the management of human resources. an analytical review. Oxford: Blackwell.

Teo, H. H.; Chan, H. C.; Wel, K. K.; Zhang, Z. 2003. Evaluating information accessibility and community adaptivity features for sustaining virtual learning communities, International Journal of Human-Computer Studies 59: 671-697. http://dx.doi.org/10.1016/S1071-5819(03)00087-9

Thomas, K.; Valthouse, B. 1990. Cognitive elements of empowerment: an interpretive model of intrinsic task motivation, Academy of Management Review 15: 666-681.

Viswesvaran, C.; Sanchez, J. I; Fisher, J. 1999. The role of social support in the process of work stress: a meta-analysis, Journal of Vocational Behavior 54: 314-334.

http://dx.doi.org/10.1006/jvbe.1998.1661

Walker, K. 2001. Building trust. Manhattan, KS: Kanas State University Cooperative Service.

Westman, M. 1992. Moderating effect of decision latitude on stress-strain relationship: does organizational level matter, Journal of Organizational Behavior 13(7): 713-722 [online], [cited 14 September 2004]. Available from Internet: http://www.jstor.org.

Zabusky, S. E.; Barley, S. R. 1996. Redefining success: ethnographic observations on the career of technicians, in P. Osterman (Ed.). Broken ladders. Oxford, New York.

Zhang, P.; Small, R. V.; Dran, G. M. V.; Barcellos, S. 2000. A two factor theory for website design, in Proc. of the $33^{\text {th }}$ Hawaii International Conference on System Science, 4-7 January, Island of Maui, USA, 1-10.

Zikmund, W. 2000. Business research methods. Chicago: The Dryden Press.

Nilufar AHSAN. Mst, holds a B.Com (Management), and M.Com in Management. Her research interest includes organizational behaviour, and ICT management area. She is currently a doctoral candidate in the Faculty of Management, Multimedia University, Cyberjaya, Malaysia.

David Yong Gun FIE is Associate Professor/Deputy Dean at the Faculty of Management, Multimedia University, Malaysia. He has published in the International Journal of American Academy of Business, the International Journal of Hospitality and Tourism Management, the International Journal Corporate Ownership and Control, the International Journal of Educational Management, the Global Review of Business and Economic Research, the International Journal of Services and Standards, the European Journal of Social Sciences and the International Journal of Business and Management Science. His research areas include strategic management, corporate governance, management, marketing and higher education.

Yeap Peik FOONG is a senior lecturer in the Faculty of Management, Multimedia University, Malaysia. His research interests include international business management, cross cultural management, strategic competitiveness and knowledge management.

Syed Shah ALAM is a senior lecturer at the Faculty of Economics and Business, Universiti Kebangsaan Malaysia (National University of Malaysia). Prior to joining to the National University of Malaysia in June 2009, he taught at Universiti Teknologi MARA (UiTM) Malaysia and Multimedia University Malaysia (MMU). Dr Alam also served MMU as a coordinator of postgraduate program at the same time. He has authored few books on E-Commerce, Internet marketing and more than 50 academic and professional articles in the reputed journals and international conferences, He has published 3 articles previously in the Journal of Business Economics and Management. His research work involves the development of E-commerce in the business field. He has been awarded the Joint Conference of e-Commerce, e-Administration, e-Society, and e-Education best paper award in 2008. His future research will focus on Internet marketing, e-commerce, mobile e-commerce, Internet and Mobile advertising. 